\title{
The Value of DNA Quantitative Cytology Test for the Screening of Endometrial Cancer
}

This article was published in the following Dove Press journal:

Cancer Management and Research

\author{
Bao-hua Yang' \\ Ming-xia Yu' \\ Jun $X u^{\prime}$ \\ Yan Su' \\ Zhi-hong $\mathrm{Ai}^{2}$ \\ 'Department of Obstetrics and \\ Gynecology, Shanghai Minhang Central \\ Hospital, Shanghai 201199, People's \\ Republic of China; ${ }^{2}$ Department of \\ Obstetrics and Gynecology, Shanghai Jiao \\ Tong University Affiliated Sixth People's \\ Hospital, Shanghai 200233, People's \\ Republic of China
}

\begin{abstract}
Objective: To evaluate the accuracy, sensitivity, and specificity of DNA quantitative cytology test for the diagnosis of endometrial cancer or precancerous lesions and then discuss the value of DNA quantitative cytology as a screening tool for endometrial cancer. Methods: The study enrolled 575 patients from September 2013 to January 2017 in Shanghai Minhang Central Hospital. Endometrial hysteroscopy plus dilation and curettage and DNA quantitative cytology tests were conducted as a method for the diagnosis of endometrial cancer. The accuracy, sensitivity, and specificity of this method were calculated according to histopathologic diagnoses which were used as the gold standard for diagnosis confirmation.
\end{abstract}

Results: For the DNA quantitative cytology diagnosis of endometrial cancer, accuracy was estimated at $85.57 \%$, sensitivity at $87.01 \%$, specificity at $85.34 \%$, positive predictive value (PPV) at $47.86 \%$, and negative predictive value (NPV) at $97.07 \%$. For the DNA quantitative cytology diagnosis of endometrial cancer in menopausal patients: accuracy was estimated at $89.95 \%$, sensitivity at $97.73 \%$, specificity at $87.59 \%$, positive predictive value (PPV) at $70.49 \%$, negative predictive value (NPV) at $99.22 \%$. For the DNA quantitative cytology diagnosis of endometrial cancer in non-menopausal patients, accuracy was estimated at $83.42 \%$, sensitivity at $72.73 \%$, specificity at $84.42 \%$, positive predictive value (PPV) at $30.38 \%$, and negative predictive value (NPV) at $97.07 \%$.

Conclusion: DNA heteroploidy can be tested for the occurrence and the development of endometrial cancer. A small number of non-endometrial cancer cases may also appear DNA heteroploidy, but the number of $>5$ c cells is less than 3 . DNA quantitative analysis is a useful tool for the screening of endometrial cancer, worthy of being popularized and applied in endometrial cancer diagnosis.

Keywords: endometrium, DNA quantitative cytology, endometrial neoplasms, precancerous conditions, screening

\section{Introduction}

Endometrial cancer is one of the most common gynecological malignancies in the world. ${ }^{1}$ In developed countries and some economically developed areas of China, the incidence of endometrial cancer ranks first among malignant tumors of female reproductive system. ${ }^{2}$ Endometrial cancer has a good prognosis in the early stage and a poor prognosis in the late stage. Therefore, the screening of endometrial cancer has been of great importance. An urgent problem to be solved is screening strategy. Up to now, there is no strategy for screening and early diagnosis of endometrial cancer in China. The diagnosis of endometrial cancer is mainly made by fractional curettage or endometrial biopsy under hysteroscopy. However, the curettage and hysteroscopy are not suitable for screening endometrial cancer
Correspondence: Zhi-hong $\mathrm{Ai}$ Department of Obstetrics and Gynecology, Shanghai Jiao Tong University Affiliated Sixth People's Hospital, Shanghai 200233, People's Republic of China Email ai_zhihong@I26.com 
because of complex operation and risks of uterine perforation, infection, and obvious pain. ${ }^{3-5}$

There is growing evidence which indicates that changes in DNA ploidy constitute an early event in the development of cancer. ${ }^{6}$ DNA ploidy has been used for screening of cervical cancer and precancerous lesions in China. ${ }^{7}$ DNA ploidy can be used for predicting the prognosis and guiding the treatment of breast cancer. ${ }^{8}$ DNA ploidy has also been used as a prognostic factor in endometrial cancer. ${ }^{9,10}$ The patients with aneuploid tumor have higher recurrence risk compared with those with diploid tumor, ${ }^{11-14}$ such as cervical cancer. In addition, DNA ploidy can be used to identify subgroups that require adjuvant therapy. ${ }^{15,16}$

In this study, endometrial cell specimens were obtained directly by endometrial cell collector. DNA quantitative analysis was carried out by liquid-based thin-layer cytology and Feulgen staining. Then, we evaluated the accuracy of DNA quantitative cytology test for the diagnosis of endometrial cancer or precancerous lesions and discussed the value of DNA quantitative cytology as a screening tool for endometrial cancer. We found that for the DNA quantitative cytology, as a tool for diagnosis of endometrial cancer, accuracy was estimated at $85.57 \%$, sensitivity at $87.01 \%$, specificity at $85.34 \%$, positive predictive value (PPV) at $47.86 \%$, and negative predictive value (NPV) at $97.07 \%$. DNA heteroploidy can be tested for the occurrence and the development of endometrial cancer. The accuracy of DNA quantitative cytology for the diagnosis of endometrial cancer was high. It will be a useful tool for the screening of endometrial cancer, worthy of being popularized and applied.

\section{Materials and Methods}

\section{Patients}

The study enrolled 575 patients for endometrial DNA quantitative cytology tests and hysteroscopy plus dilation and curettage from September 2013 to January 2017 in Shanghai Minhang Central Hospital. All patients were divided into two groups: non-menopausal and menopausal. Each group was further classified according to the presence or absence of uterine bleeding. Inclusion criteria: (1) Abnormal uterine bleeding (AUB); (2) Postmenopausal bleeding (PMUB); (3) Menopausal patients who had no clinical symptoms, while were diagnosed as intrauterine heterogeneity or their endometrial thickness is $\geq 5 \mathrm{~mm}$ by transvaginal color Doppler sonography, ${ }^{17}$ (4) Non-menopausal female without clinical symptoms, who were diagnosed as intrauterine heterogeneity or their endometrial thickness is $\geq 15 \mathrm{~mm}$ by vaginal color
Doppler ultrasound within 1 week after menstruation; (5) This study was approved by the Ethical Committee of Shanghai Minhang District Central Hospital. After informed, these patients were willing to participate in the research of this project and cooperate and provided a written consent. This study was conducted in accordance with the Declaration of Helsinki. Exclusion criteria: (1) Bleeding caused by vulvar, vaginal, cervical, uterine fibroids, adenomyosis, or ovarian lesions; (2) Vaginal bleeding due to pregnancy-related diseases during reproductive period; (3) Acute vaginitis or cervicitis; (4) Acute or subacute pelvic inflammatory disease; (5) Acute severe systemic disease; (6) Preoperative body temperature $>37.5^{\circ} \mathrm{C}$.

\section{Collection of Cytological and Histopathological Specimens}

After the patients were intravenously anesthetized, endometrial cells were collected firstly with a disposable cell collector. The specimens were placed in cell preservation solution and sent to the cytology center of the hospital for parallel DNA quantitative analysis within $24 \mathrm{hrs}$. After hysteroscopic curettage or placeholder resection, the tissue specimens were fixed with regular formaldehyde solution and sent to pathology department of our hospital for histopathological examination.

Endometrial cell collector ${ }^{18}$ (developed by Shanghai Yudu Technology Co., Ltd.) had an outer cannula with a brush at the front end, which was $(16 \pm 0.5) \mathrm{mm}$ in length and $(10 \pm 0.5) \mathrm{mm}$ in diameter. Before and after the collection of specimens in the uterine cavity, the brush was buried in the cannula to prevent contamination of cells by the uterine cavity. The cell collection brush was slowly fed into the uterus fundus under the protection of the outer cannula. Then, the outer cannula was retracted to expose the collection ring, and the collection ring was rotated in the same direction (clockwise or counterclockwise) for 10 cycles. At last, the brush was pulled back into the cannula and withdrawn from the cervix. Put the collection brush back into the cell preservation solution (provided by McAudie Medical Diagnostic Systems Co., Ltd.). Liquidbased thin-layer cell preparation and Feulgen staining were used to detect these cells.

Histopathological sections were independently read by two pathologists. The diagnosis of histopathology refers to WHO diagnostic criteria of 2003. ${ }^{19}$ According to the pathological classification criteria of uterine tissues, they are categorized as follows: (1) no abnormalities (including atrophic 
endometrium, proliferative, or secretory endometrium); (2) benign endometrial lesions (including endometrial polyps, simple proliferative endometrium, complex proliferative endometrium, endometrium inflammation, submucosal myoma, etc.); (3) atypical hyperplasia of endometrium; (4) endometrial cancer.

\section{Cellular DNA Analysis and Diagnostic Criteria}

All Feulgen stained slides were scanned with DNA image cytometry (DNA-ICM) from MacDivision Medical Diagnostic Systems. DNA-ICM determined the content of nuclei by measuring the integrated optical density (IOD) of the stained nuclei. The cellular DNA content was measured in terms of c (content), G1/G0 was 2c cells (diploid cells), and $\mathrm{G} 2 / \mathrm{M}$ cells were $4 \mathrm{c}$ cells (tetraploid cells). Under normal circumstances, there are no aneuploid cells, except for $\mathrm{S}$ phase cells with DNA content between 2c and 4c. However, when carcinogenesis happens, aneuploid cells appear. The systems can read more than 6000 cells per slide. Each nucleus after scanning had 123 eigenvalues, including morphological characteristics, light absorption characteristics, specific structural characteristics, Markovian and nonMarkovian structural features, and length characteristics. DNA-ICM automatically performed cell sorting and counting processes based on different characteristic parameters of different cell components. The standard controlled cells were 100 normal epithelial cells and some lymphocytes on the same slide. The measured IOD was a $2 c$ reference value. Each nuclei could be classified according to different parameters: normal diploid cells (DNA content is 2c), hyperplasia or suspected diseased cells (DNA content is $2.5-5 \mathrm{c}$ ), and diseased cells (DNA content $>5 \mathrm{c}$ ). For those slides with DNA content $>5 \mathrm{c}$ aneuploid cells, they needed to be checked by a pathologist professionally under the microscope to exclude mistaking the rubbish and overlapping nuclei for cancer cells or abnormal cells. Evaluation of results: For DNA ploidy analysis results, cells with DNA content $>5 \mathrm{c}$ or proliferating cells account for more than $10 \%$ of the total number of detected cells or with aneuploid cell peaks were positive results, and vice versa. ${ }^{20}$

\section{Statistics}

SPSS 17.0 software was used for statistical analysis of the data. Data were expressed as mean \pm standard deviation. Chi-square test was used to evaluate the difference between the two groups, with $\mathrm{P}<0.05$ set as the significant level. The coincidence, sensitivity, specificity, positive predictive value, and negative predictive value of DNA quantitative analysis in diagnosis of endometrial atypical hyperplasia and endometrial cancer were calculated according to the gold standard of histopathological diagnosis. DNA quantitative analysis showed the difference of aneuploid cells in different endometrial tissues.

\section{Results}

The Accuracy Evaluation of Endometrial Cell DNA Quantitative Analysis in Screening Endometrial Cancer and Its Precancerous Lesions

We compared the endometrial DNA quantitative analysis results and the clinical histopathological results. With histopathological diagnosis as the "gold standard", we analyzed the coincidence, sensitivity, specificity, false negative rate, false positive rate, negative predictive value, and positive predictive value of endometrial DNA quantitative analysis for screening endometrial cancer and its precancerous lesions.

For the DNA quantitative cytology diagnosis of endometrial cancer in all patients, accuracy was estimated at $85.57 \%$, sensitivity at $87.01 \%$, specificity at $85.34 \%$, the false negative rate was $12.99 \%$, the false positive rate was

Table I Comparative Analysis of DNA Quantitative Analysis and Pathological Diagnosis for 575 Cases

\begin{tabular}{|c|c|c|c|c|c|c|c|c|c|c|}
\hline \multirow{3}{*}{$\begin{array}{l}\text { DNA- } \\
\text { Quantification }\end{array}$} & \multicolumn{8}{|c|}{ Histopathological Diagnosis of Endometrium } & \multirow{2}{*}{\multicolumn{2}{|c|}{ Total }} \\
\hline & \multicolumn{2}{|c|}{ Normal } & \multicolumn{2}{|c|}{ Benign Lesion } & \multicolumn{2}{|c|}{$\begin{array}{l}\text { Atypical } \\
\text { Hyperplasia }\end{array}$} & \multicolumn{2}{|c|}{ Cancer } & & \\
\hline & $\begin{array}{l}\text { No. } \\
\text { (n) }\end{array}$ & $\begin{array}{l}\text { Percent } \\
\text { (\%) }\end{array}$ & $\begin{array}{l}\text { No. } \\
\text { (n) }\end{array}$ & $\begin{array}{l}\text { Percent } \\
\text { (\%) }\end{array}$ & $\begin{array}{l}\text { No. } \\
\text { (n) }\end{array}$ & $\begin{array}{l}\text { Percent } \\
\text { (\%) }\end{array}$ & $\begin{array}{l}\text { No. } \\
\text { (n) }\end{array}$ & $\begin{array}{l}\text { Percent } \\
\text { (\%) }\end{array}$ & $\begin{array}{l}\text { No. } \\
\text { (n) }\end{array}$ & $\begin{array}{l}\text { Percent } \\
\text { (\%) }\end{array}$ \\
\hline Positive & 15 & 12.93 & 58 & 15.18 & 24 & 80.00 & 43 & 91.49 & 140 & 24.35 \\
\hline Negative & 101 & 87.07 & 324 & 84.82 & 6 & 20.00 & 4 & 8.51 & 435 & 75.65 \\
\hline Total & 116 & 20.17 & 382 & 66.44 & 30 & 5.22 & 47 & 8.17 & 575 & 100.00 \\
\hline
\end{tabular}


$14.66 \%$, positive predictive value (PPV) at $47.86 \%$, and negative predictive value (NPV) at $97.07 \%$ (Table 1).

For the DNA quantitative cytology diagnosis of endometrial cancer in menopausal patients, accuracy was estimated at $89.95 \%$, sensitivity at $97.73 \%$, specificity at $87.59 \%$, the false negative rate was $2.27 \%$, the false positive rate was $12.41 \%$, positive predictive value (PPV) at $70.49 \%$, and negative predictive value (NPV) at $99.22 \%$ (Table 2).

For the DNA Quantitative Cytology diagnosis of endometrial cancer in non-menopausal patients, accuracy was estimated at $83.42 \%$, sensitivity at $72.73 \%$, specificity at $84.42 \%$, the false negative rate was $27.27 \%$, the false positive rate was $15.58 \%$, positive predictive value (PPV) at 30.38\%, and negative predictive value (NPV) at 97.07\% (Table 3).

\section{Quantitative Analysis of DNA Images of Different Endometrial Tissues}

DNA index (DI) means the ratio of the DNA-IOD value of the tested cells to that of the normal cells. As shown in Figure 1, most of the cells were at the position of DI 1, while a small number of proliferating cells were at the position of DI 1-2. The quantitative DNA analysis images and cytological images of endometrial carcinoma are shown in Figure 2. As can be seen from the figure, a large number of DNA aneuploidy cells formed two peaks at DI 1.5-2.0 and DI 3.5-4.

Then, we compared the proportion of DNA aneuploid $>5$ c cells by DNA quantitative analysis in different endometrial tissues. As mentioned earlier, cells with a DNA aneuploid $>5 \mathrm{c}$ are considered diseased cells. Comparison in Table 4 showed that there were statistically significant differences between normal endometrium and endometrial dysplasia $\left(\chi^{2}=91.966^{\mathrm{a}}, \mathrm{P}=0.000\right)$, normal endometrium and endometrial carcinoma $\left(\chi^{2}=123.64^{\mathrm{a}}, \mathrm{P}=0.000\right)$, benign lesions and endometrial dysplasia $\left(\chi^{2}=202.412^{\mathrm{a}}, \mathrm{P}=0.000\right)$, and benign and endometrial carcinoma $\left(\chi^{2}=285.631^{\mathrm{a}}\right.$, $\mathrm{P}=0.000)$. There was no significant difference between normal endometrium and benign lesions $\left(\chi^{2}=2.190^{\mathrm{a}}, \mathrm{P}=0.334\right)$, and endometrial dysplasia and endometrial cancer $\left(\chi^{2}=5.905^{\mathrm{a}}, \mathrm{P}=0.116\right)$. Table 4 shows that the higher the number of $>5 \mathrm{c}$ cells, the higher the risk of endometrial cancer.

\section{Discussion}

Endometrial cancer is one of the most common gynecological malignancies. Early endometrial cancer usually has a good prognosis, while advanced endometrial cancer has a poor prognosis. $^{21}$ Screening for endometrial cancer facilitates early diagnosis and treatment, thus improving survival. However, at present, there is a lack of ideal screening methods for endometrial cancer.

In the process of tumor development, the abnormal structure and function of DNA are the molecular basis of cell malignant transformation, and measuring changes in DNA content is better than looking at changes in overall cell morphology. DNA aneuploidy is a proven good marker for prospective malignancy. ${ }^{22-24}$ DNA quantitative cytology aims to identify the DNA stem lines outside the euploid regions as aneuploid at a defined statistical level of significance. DNA quantitative cytology can accurately reflect various kinds of image information in the form of data combined with microscopy and digital image analysis. ${ }^{25}$ This method allows pathology to be transformed from a traditional descriptive morphological approach to a quantitative analysis that is more objective and reproducible. ${ }^{26}$ However, there are few studies using endometrial cell DNA quantitative analysis to screen endometrial cancer and its precancerous lesions.

Multiple studies have confirmed that the heteroploid rate of endometrial cancer is $72-85 \% .^{27,28}$ In this study, we found that the heteroploid of endometrial cancer at a rate of

Table 2 Comparative Analysis of DNA Quantitative Analysis and Pathological Diagnosis in Menopause Patients

\begin{tabular}{|c|c|c|c|c|c|c|c|c|c|c|}
\hline \multirow{3}{*}{$\begin{array}{l}\text { DNA } \\
\text { Quantification }\end{array}$} & \multicolumn{8}{|c|}{ Histopathological Diagnosis of Endometrium } & \multirow{2}{*}{\multicolumn{2}{|c|}{ Total }} \\
\hline & \multicolumn{2}{|c|}{ Normal } & \multicolumn{2}{|c|}{ Benign Lesion } & \multicolumn{2}{|c|}{$\begin{array}{l}\text { Atypical } \\
\text { Hyperplasia }\end{array}$} & \multicolumn{2}{|c|}{ Cancer } & & \\
\hline & $\begin{array}{l}\text { No. } \\
\text { (n) }\end{array}$ & $\begin{array}{l}\text { Percent } \\
(\%)\end{array}$ & $\begin{array}{l}\text { No. } \\
\text { (n) }\end{array}$ & $\begin{array}{l}\text { Percent } \\
\text { (\%) }\end{array}$ & $\begin{array}{l}\text { No. } \\
\text { (n) }\end{array}$ & $\begin{array}{l}\text { Percent } \\
\text { (\%) }\end{array}$ & $\begin{array}{l}\text { No. } \\
\text { (n) }\end{array}$ & $\begin{array}{l}\text { Percent } \\
\text { (\%) }\end{array}$ & $\begin{array}{l}\text { No. } \\
\text { (n) }\end{array}$ & $\begin{array}{l}\text { Percent } \\
\text { (\%) }\end{array}$ \\
\hline Positive & 3 & 8.33 & 15 & 13.76 & 8 & 88.89 & 35 & 100 & 61 & 32.28 \\
\hline Negative & 33 & 91.67 & 94 & 86.24 & 1 & II.II & 0 & 0 & 128 & 67.72 \\
\hline Total & 36 & 19.05 & 109 & 57.67 & 9 & 4.76 & 35 & 18.52 & 189 & 100.00 \\
\hline
\end{tabular}


Table 3 Comparative Analysis of DNA Quantitative Analysis and Pathological Diagnosis in Non-Menopausal Patients

\begin{tabular}{|c|c|c|c|c|c|c|c|c|c|c|}
\hline \multirow{3}{*}{$\begin{array}{l}\text { DNA } \\
\text { Quantification }\end{array}$} & \multicolumn{8}{|c|}{ Histopathological Diagnosis of Endometrium } & \multirow{2}{*}{\multicolumn{2}{|c|}{ Total }} \\
\hline & \multicolumn{2}{|c|}{ Normal } & \multicolumn{2}{|c|}{ Benign Lesion } & \multicolumn{2}{|c|}{$\begin{array}{l}\text { Atypical } \\
\text { Hyperplasia }\end{array}$} & \multicolumn{2}{|c|}{ Cancer } & & \\
\hline & $\begin{array}{l}\text { No. } \\
\text { (n) }\end{array}$ & $\begin{array}{l}\text { Percent } \\
\text { (\%) }\end{array}$ & $\begin{array}{l}\text { No. } \\
\text { (n) }\end{array}$ & $\begin{array}{l}\text { Percent } \\
\text { (\%) }\end{array}$ & $\begin{array}{l}\text { No. } \\
\text { (n) }\end{array}$ & $\begin{array}{l}\text { Percent } \\
\text { (\%) }\end{array}$ & $\begin{array}{l}\text { No. } \\
\text { (n) }\end{array}$ & $\begin{array}{l}\text { Percent } \\
\text { (\%) }\end{array}$ & $\begin{array}{l}\text { No. } \\
\text { (n) }\end{array}$ & $\begin{array}{l}\text { Percent } \\
\text { (\%) }\end{array}$ \\
\hline Positive & 12 & 15 & 43 & 15.75 & 16 & 76.19 & 8 & 66.67 & 79 & 20.47 \\
\hline Negative & 68 & 85 & 230 & 84.25 & 5 & 23.81 & 4 & 33.33 & 307 & 79.53 \\
\hline Total & 80 & 20.72 & 273 & 70.73 & 21 & 5.44 & 12 & 3.11 & 386 & 100.00 \\
\hline
\end{tabular}

$87.01 \%$, slightly higher than that of previous studies, which may be associated with the following factors: (1) In previous studies, paraffin-embedded endometrial tissue or fresh endometrial tissue imprints were mostly used to obtain endometrial single-cell suspension after treatment, with many broken cells and impurities, which affected image analysis. When sampling, only one part of the tumor was detected, which could not reflect the real characteristics of the tumor, thus affecting the accuracy of the results. In this study, cells were collected from endometrial cell collectors for thin layer preparation of liquid-based cells. Endometrial cells were obtained directly, so more cells were obtained, with less cell fragmentation, less tissue debris, and other impurities. Evenly distributing the cell monolayer on the glass slide can preserve the cell structure and DNA in the nucleus in a good state, which will increase the detection rate of heteroploid. ${ }^{29,30}$ (2) Previous studies on DNA ploidy mostly adopted flow cytometry. However, the sensitivity of flow cytometry to detect DNA content was not ideal. The determination of DNA-ICM may cause errors only when the number of sample cells is less than 300. DNA quantitative analysis system was used for the diagnosis of breast cancer, ${ }^{31}$ gastric cancer, ${ }^{32}$ and the benign and malignant differentiation of ascites, ${ }^{33}$ with the sensitivity of $78 \%$ to $94 \%$, which is basically consistent with our study.

In this study, for the DNA quantitative cytology diagnosis of endometrial cancer in all patients, accuracy was estimated at $85.57 \%$, sensitivity at $87.01 \%$, specificity at $85.34 \%$, the false negative rate was $12.99 \%$, the false positive rate was $14.66 \%$, positive predictive value at $47.86 \%$, and negative predictive value at $97.07 \%$. Patients were further divided into menopausal group and nonmenopausal group. Endometrial DNA quantitative analysis was used to screen endometrial cancer and its precancerous lesions in each group. For the DNA quantitative cytology diagnosis of endometrial cancer in menopausal group, accuracy was estimated at $89.95 \%$, sensitivity at $97.73 \%$, specificity at $87.59 \%$, the false negative rate was $2.27 \%$, the false positive rate was $12.41 \%$, positive predictive value at $70.49 \%$, and negative predictive value at $99.22 \%$. For the DNA quantitative cytology diagnosis of endometrial cancer in non-menopausal group, accuracy was estimated at $83.42 \%$, sensitivity at $72.73 \%$, specificity at $84.42 \%$, the false negative rate was $27.27 \%$, the false positive rate was $15.58 \%$, positive predictive value at $30.38 \%$, and negative predictive value at $97.07 \%$. From the results, we could see that endometrial DNA quantitative analysis had a higher sensitivity for screening endometrial cancer and its precancerous lesions in postmenopausal patients. But the specificity was higher in both postmenopausal and nonmenopausal groups.

In this study, DNA quantitative analysis missed the diagnosis of 6 cases of endometrial dysplasia, including 1 case of postmenopausal patients. In this case, the lesion found by hysteroscopy was located at the right uterine horn and the lesion scope was small and limited, so the missed diagnosis may be related to the sampling. The other 5 cases were all non-menopausal patients with abnormal uterine bleeding. There were 47 cases of endometrial cancer, and 4 cases were missed by DNA quantitative analysis, all of which were highly differentiated endometrioid adenocarcinoma, and all of them were cases with irregular vaginal bleeding during perimenopause. After the operation, the uterine specimens of these 4 cases were brushed at the lesion site again for DNA quantitative analysis, and the results showed that 1 case was DNA positive, and the remaining 3 cases were still DNA negative, which may be because some welldifferentiated endometrioid carcinoma with low histological and cytological atypia was a diploid cell tumor, resulting in negative DNA quantitative analysis. DNA quantitative analysis could not find diploid tumor, and combination with P53, PTEN gene detection and other 


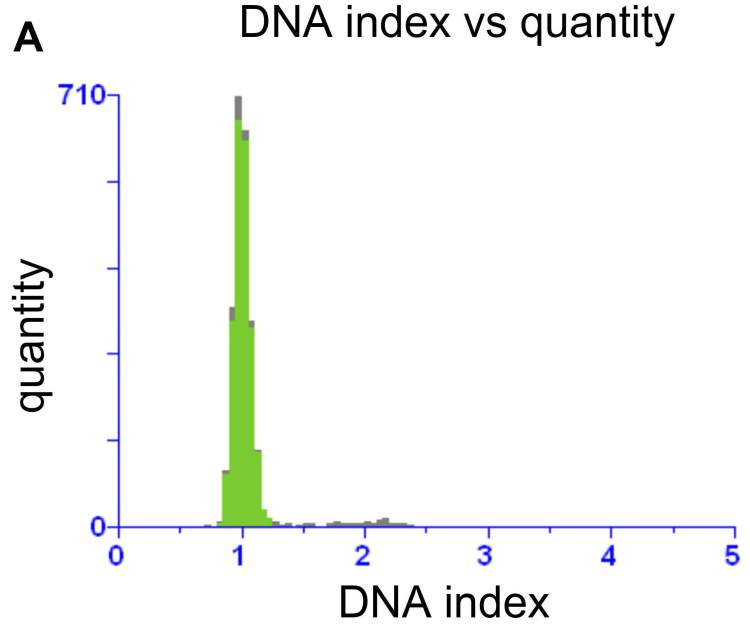

DNA index vs area

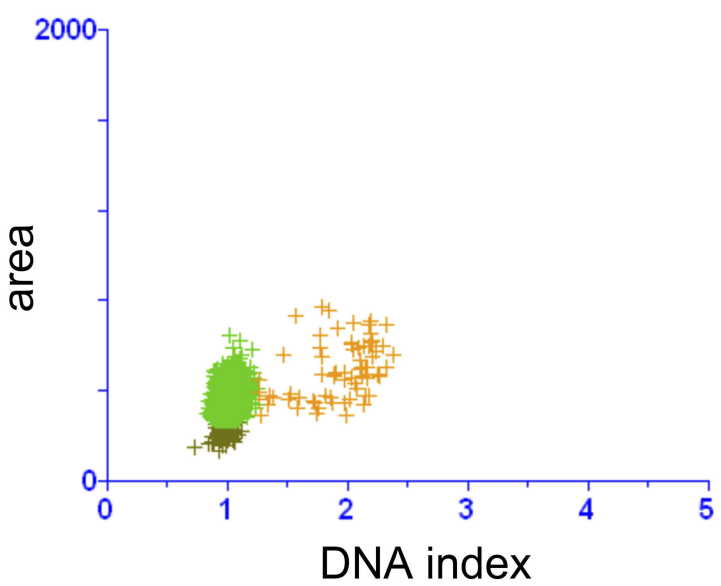

B

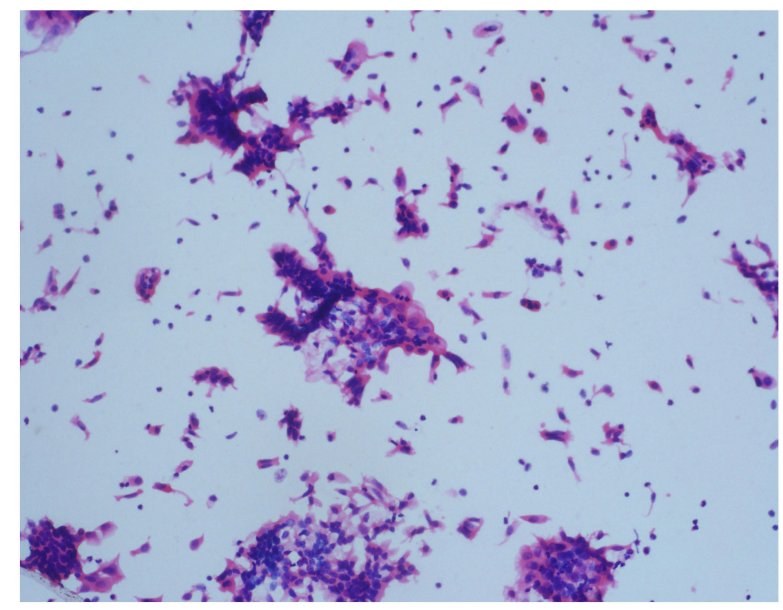

Image for cell nucleus and DI
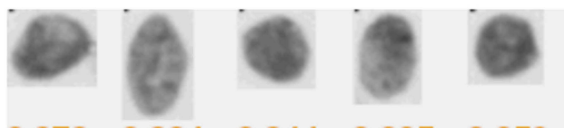

2.373

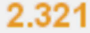

2.314

2.285

$2.259 \quad 2.240$
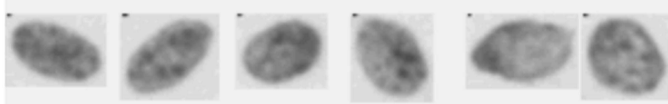

2.239

2.205

2.202

2.193

2.189

2.181
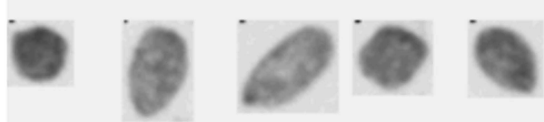

2.173

2.172

2.171

2.164

2.162

2.161
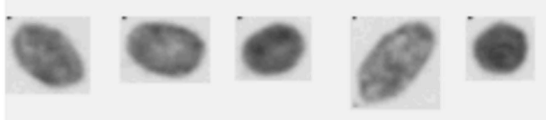

2.158

2.144

2.139

2.130

2.129

2.122
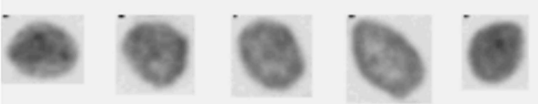

2.115

2.102
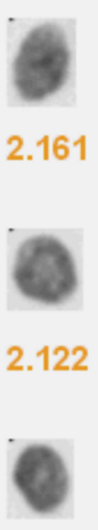

2.060

C

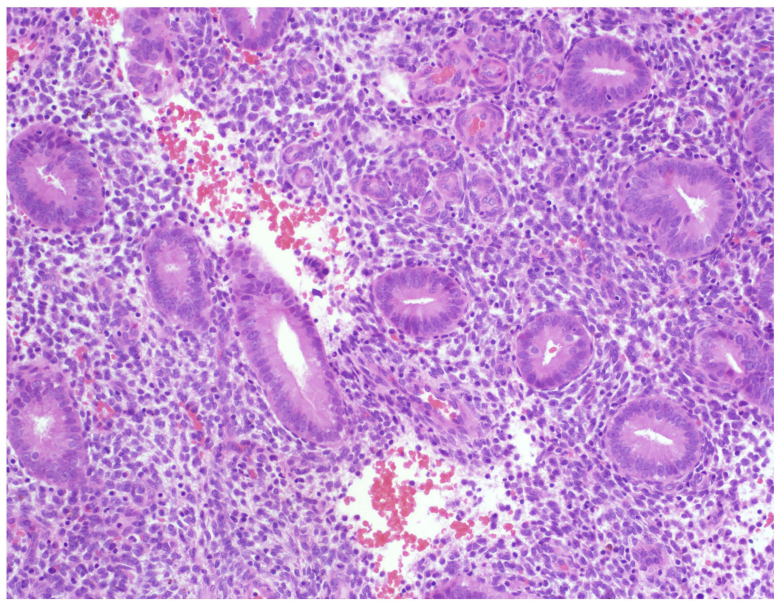

Figure I DNA quantitative analysis and cytological histopathological diagnosis of normal endometrium. (A) Quantitative analysis of DNA images of normal proliferative endometrium. DI, DNA index for short, which means the ratio of the DNA-IOD value of the tested cells to that of the normal cells. Cytological images (System scan cell under magnification, $\times 20$.) (B) and histopathological images (magnification, $\times 200$.) (C) of normal proliferative normal endometrium. 

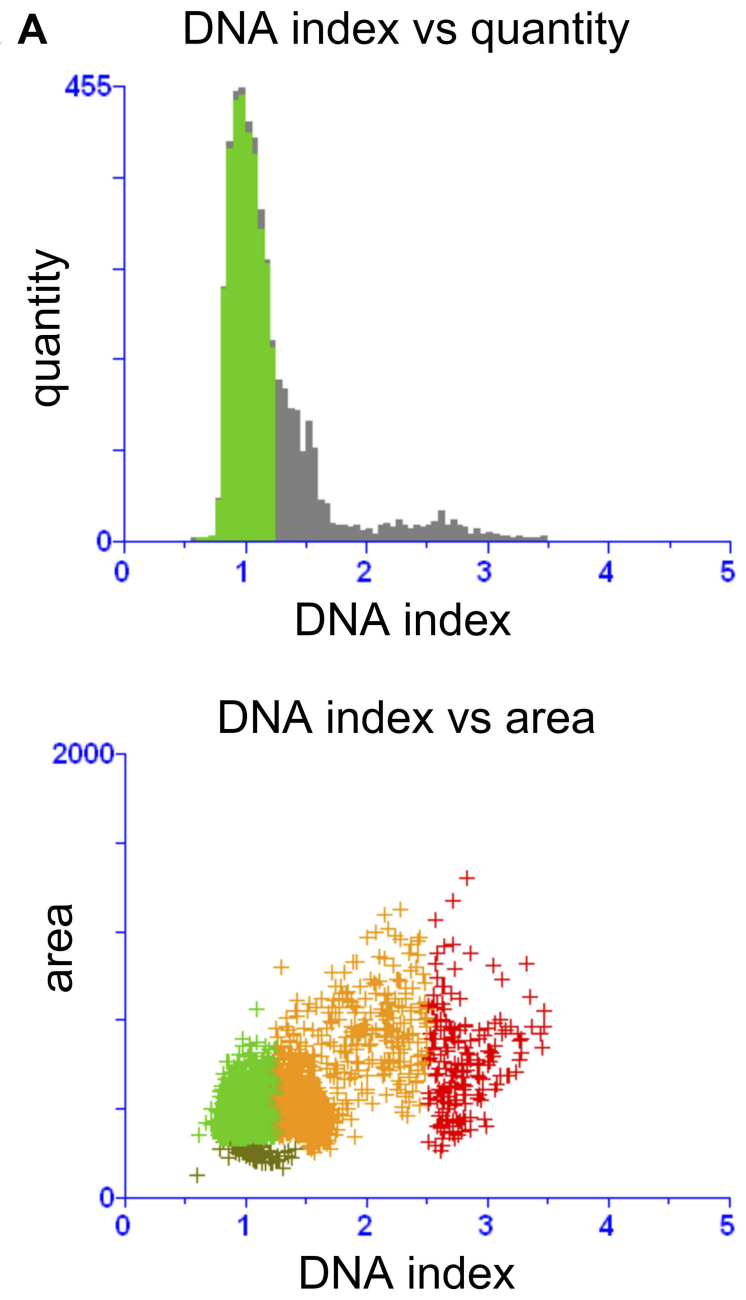

B

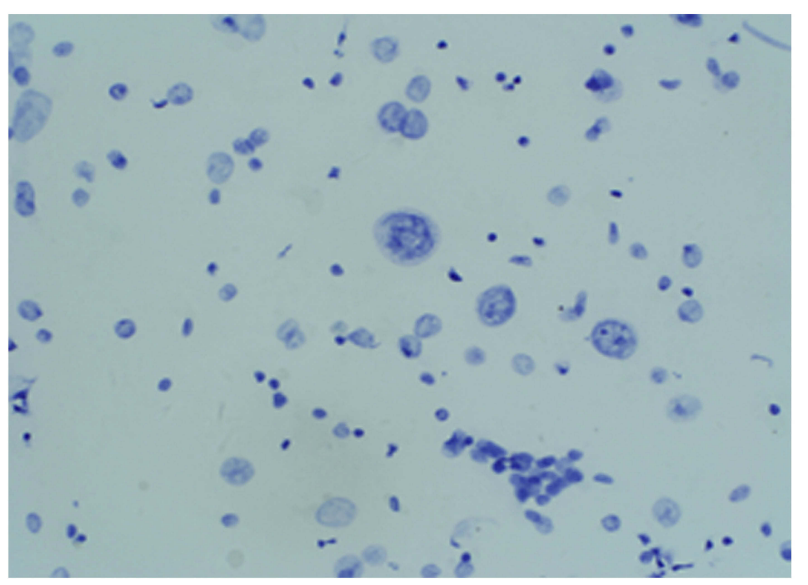

\section{Image for cell nucleus and DI}
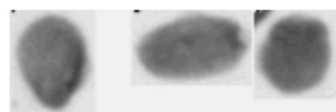

3.470

3.460

3.450

3.440

3.358

3.348
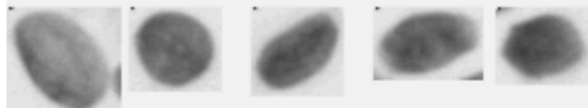

3.323

3.282

3.269

3.258

3.254

3.246
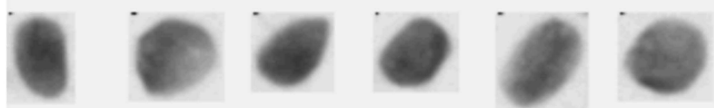

3.224

3.192

3.170

3.156

3.139

3.121
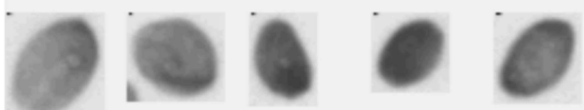

3.118

3.102

3.097

3.072

3.061

3.059
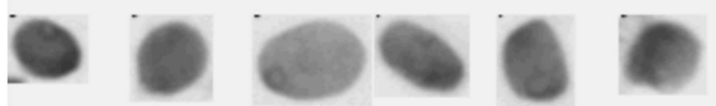

$\begin{array}{llllll}3.053 & 3.041 & 3.040 & 3.031 & 3.016 & 3.010\end{array}$

\section{C}

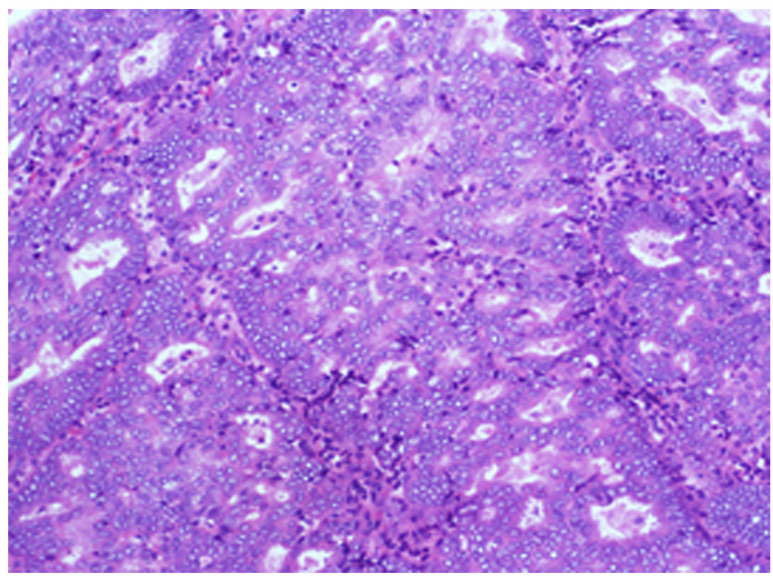

Figure 2 DNA quantitative analysis and cytological histopathological diagnosis of endometrial carcinoma. (A) Quantitative analysis of DNA images of endometrial carcinoma. DI, DNA index for short, which means the ratio of the DNA-IOD value of the tested cells to that of the normal cells. Cytological images (System scan cell under magnification, $\times 20$.) (B) and histopathological images (magnification, $\times 200$.) (C) of endometrial carcinoma. 
Table 4 Comparison of the Cell Types in Different Endometrium Groups with DNA Aneuploid >5c

\begin{tabular}{|c|c|c|c|c|c|c|c|c|}
\hline \multirow[t]{3}{*}{ Groups of Endometrium (n) } & \multicolumn{8}{|c|}{ >5c Aneuploid Cell Type } \\
\hline & \multicolumn{2}{|l|}{ None } & \multicolumn{2}{|c|}{ Small Amount } & \multicolumn{2}{|l|}{ Visible } & \multicolumn{2}{|c|}{ Large Amount } \\
\hline & No. (n) & Percent (\%) & No. (n) & Percent (\%) & No. (n) & Percent (\%) & No. (n) & Percent (\%) \\
\hline Normal (I16) & 101 & 87.07 & 15 & 12.93 & 0 & 0 & 0 & 0 \\
\hline Benign lesion (382) & 324 & 84.82 & 51 & 13.35 & 7 & 1.83 & 0 & 0 \\
\hline Atypical hyperplasia (30) & 6 & 20.00 & 4 & 13.33 & 13 & 43.34 & 7 & 23.33 \\
\hline Cancer (47) & 4 & 8.51 & 6 & 12.77 & 14 & 29.79 & 23 & 48.93 \\
\hline
\end{tabular}

Notes: DNA aneuploidy cell type was classified into 4 different types according to the number of $>5 \mathrm{c}$ aneuploid cells. None, without any $>5 \mathrm{c}$ aneuploid cells; Small amount, with I-2 $>5$ c aneuploid cells insight; Visible, with 3-9>5c aneuploid cells; Large amount, $\geq 10>5$ c aneuploid cells.

methods could improve its accuracy. In this study, there was no missed diagnosis of type II endometrial cancer in the DNA quantitative analysis, which was consistent with the literature reports. ${ }^{34}$

In this study, it was also found that a few cases of nonendometrial cancer could also present DNA aneuploidy cells, but $>5 \mathrm{c}$ cells were few, mostly $1-2$. When inflammation occurs, there is an increase in the number of cells entering the cell cycle (i.e., the S-G2-M phase), but this part does not exceed $10 \%$ of all cells. In patients with endometrial dysplasia and endometrial cancer, the proportion of more than three $>5 \mathrm{c}$ cells exceeded $10 \%$. And, the more heteroploid cells in $>5 \mathrm{c}$, the greater the risk it has for endometrial cancer and its precancerous lesions.

To sum up, DNA quantitative analysis of endometrium is a simple, safe, painless, accurate, objective, and repeatable method for screening endometrial cancer and its precancerous lesions, and is also a feasible one, which has clinical application value. DNA quantitative analysis is especially suitable for screening high-risk groups of menopausal endometrial cancer. However, the number of cases in this study is not large enough. It needs to be further confirmed by expanding the sample size in future studies.

\section{Acknowledgments}

This study was supported by the Natural Science Foundation of Minhang District, Shanghai (Grant No. 2014MHZ017 to Dr. Baohua Yang) and the Natural Science Foundation of Shanghai (Grant No. 17ZR1421400 to Dr. Zhihong Ai).

\section{Disclosure}

All authors confirm that there are no conflicts of interest in this study.

\section{References}

1. Siegel RL, Miller KD, Jemal A. Cancer statistics, 2016. CA Cancer J Clin. 2016;66(1):7-30. doi:10.3322/caac.21332

2. Siegel RL, Miller KD, Jemal A. Cancer statistics, 2015. CA Cancer J Clin. 2015;65(1):5-29. doi:10.3322/caac.21254

3. Kipp BR, Medeiros F, Campion MB, et al. Direct uterine sampling with the Tao brush sampler using a liquid-based preparation method for the detection of endometrial cancer and atypical hyperplasia. Cancer. 2008;114:228-235. doi:10.1002/cncr.23636

4. Rauf RSA, Sadia S, Waqar F, Zafar S, Sultana SWS. Outpatient endometrial biopsy with Pipelle vs diagnostic dilatation and curettage. J Ayub Med Coll Abbottabad. 2004;26:145-148.

5. Cooper JM, Erickson ML. Endometrial sampling techniques in the diagnosis of abnormal uterine bleeding. Obstet Gynecol Clin North Am. 2000;27:235-244. doi:10.1016/S0889-8545(00)80018-2

6. Sudbo J, Reith A. The evolution of predictive oncology and molecular-based therapy for oral cancer prevention. Int $J$ Cancer. 2005;115:339-345. doi:10.1002/ijc.20896

7. Garner D. Clinical application of DNA ploidy to cervical cancer screening: A review. World J Clin Oncol. 2014;5(5):931-965. doi:10.5306/wjco.v5.i5.931

8. Fitzgibbons PL, Page DL, Weaver D, et al. Prognostic factors in breast cancer. College of American Pathologists Consensus Statement 1999. Arch Pathol Lab Med. 2000;124:966-978. doi:10.1043/0003-9985(2000)124<0966:PFIBC >2.0.CO;2

9. Salvesen HB, Akslen LA. Molecular pathogenesis and prognostic factors in endometrial carcinoma. APMIS. 2002;110:673-689. doi:10.1034/j.1600-0463.2002.1101001.x

10. Terada K, Mattson D, Goo D, Shimizu D. DNA aneuploidy is associated with increased mortality for stage I endometrial cancer. Gynecol Oncol. 2004;95:483-487. doi:10.1016/j.ygyno.2004.08.031

11. Pradhan M, Abeler VM, Danielsen HE, et al. Prognostic importance of DNA ploidy and DNA index in stage I and II endometrioid adenocarcinoma of the endometrium. Ann Oncol. 2012;23:1178-1184. doi:10.1093/annonc/mdr368

12. D’Urso V, Collodoro A, Mattioli E, Giordano A, Bagella L. Cytometry and DNA ploidy: clinical uses and molecular perspective in gastric and lung cancer. $J$ Cell Physiol. 2010;222:532-539.

13. Nghiem VT, Davies KR, Beck JR, et al. Economic evaluation of DNA ploidy analysis vs liquid-based cytology for cervical screening. Br J Cancer. 2015;112:1951-1957. doi:10.1038/bjc.2015.95

14. Gordon DJ, Resio B, Pellman D. Causes and consequences of aneuploidy in cancer. Nat Rev Genet. 2012;13(3):189-203. doi:10.1038/ $\operatorname{nrg} 3123$

15. Njølstad TS, Trovik J, Hveem TS, et al. DNA ploidy in curettage specimens identifies high-risk patients and lymph node metastasis in endometrial cancer. $\mathrm{Br} \quad J$ Cancer. 2015;112(10):1656-1664. doi:10.1038/bjc.2015.123 
16. Lindahl B, Masback A, Persson J, et al. Adenocarcinoma corpus uteri stage I-II: results of a treatment programme based upon cytometry. Anticancer Res. 2009;29:4731-4735.

17. Mangili G, Montoli S, De Marzi P, et al. The role of DNA ploidy in postoperative management of stage I endometrial cancer. Ann Oncol. 2008;19:1278-1283. doi:10.1093/annonc/mdn041

18. Du J, Li Y, Lv S, et al. Endometrial sampling devices for early diagnosis of endometrial lesions. $J$ Cancer Res Clin Oncol. 2016;142:2515-2522. doi:10.1007/s00432-016-2215-3

19. Dueholm M, Moller C, Rydbjerg S, et al. An ultrasound algorithm for identification of endometrial cancer. Ultrasound Obstet Gynecol. 2014;43(9):557-568. doi:10.1002/uog.13205

20. World Health Organization classification of tumours; Tavassoli FA, Devilee P. Pathology and Genetic of Tumours of the Breast and Female Genital Organs. Lyon: IARC Press; 2003.

21. Guillaud M, Benedet JL, Cantor SB, et al. DNA ploidy compared with human papilloma virus testing (Hybrid Capture II) and conventional cervical cytology as a primary screening test for cervical high-grade lesions and cancer in 1555 patients with biopsy confirmation. Cancer. 2006;107(2):309-318. doi:10.1002/(ISSN)1097-0142

22. Tang JS, Anderson BO, See HT, et al. Management of endometrial cancer in Asia: consensus statement from the Asian Oncology Summit. Lancet Oncol. 2009;10(11):1119-1127. doi:10.1016/S1470-2045(09) 70290-6

23. Olaharski AJ, Sotelo R, Solorza-Luna G, et al. Tetraploidy and chromosomal instability are early events during cervical carcinogenesis. Carcinogenesis. 2006;27:337-343. doi:10.1093/carcin/bgi218

24. Torres-Rendon A, Stewart R, Craig GT, Wells M, Speight PM. DNA ploidy analysis by image cytometry helps to identify oral epithelial dysplasias with a high risk of malignant progression. Oral Oncol. 2009;45:468-473. doi:10.1016/j.oraloncology.2008.07.006

25. Padilla-Nash HM, Hathcock K, McNeil NE, et al. Spontaneous transformation of murine epithelial cells requires the early acquisition of specific chromosomal aneuploidies and genomic imbalances. Genes Chromosomes Cancer. 2012;51:353-374. doi:10.1002/gcc.21921
26. Duarte CEM, Carvalho CR, Silva-Filho ALD. Adaptation of image cytometry methodology for DNA ploidy analysis of cervical epithelium samples: a pilot study. Taiwan $J$ Obstet Gynecol. 2014;53:227-231. doi:10.1016/j.tjog.2014.04.019

27. Song T, Lee JW, Kim HJ, et al. Prognostic significance of DNA ploidy in stage I endometrial cancer. Gynecol Oncol. 2011;122 (1):79-82. doi:10.1016/j.ygyno.2011.03.017

28. Susini T, Rapi S, Massi D, et al. Preoperative evaluation of tumor ploidy in endometrial carcinoma. Cancer. 1999;86:1005-1012.

29. Bocking A, Nguyen VQH. Diagnostic and prognostic use of DNA image cytometry in cervical squamous intraepithelial lesions and invasive carcinoma. Cancer Cytopathol. 2004;102:41-54. doi:10. 1002/cncr. 11889

30. Kondo E, Tabata T, Koduka Y, et al. What is the best method of detecting endometrial cancer in outpatients?-endometrial sampling, suction curettage, endometrial cytology. Cytopathology. 2008;19 (10):28-33. doi:10.1111/j.1365-2303.2007.00509.x

31. Williams AR, Brechin S, Porter AJ, et al. Factors affecting adequacy of Pipelle and Tao Brush endometrial sampling. BJOG. 2008;115:1028-1036 $\square$. doi:10.1111/j.1471-0528.2008.01773.x

32. Ross JS, Lintte GP, Ross MS, et al. DNA ploidy and cell cycle analysis in breast cancer. Am J Clin Pathol. 2003;120(Suppl):S7284. doi:10.1309/QD096UGF70T5H46G

33. Osterheld MC, Caron L, Demierre M, et al. DNA-ploidy in advanced gastric carcinoma is less heterogeneous than in early gastric cancer. Cell Oncol. 2004;26(1-2):21-29. doi:10.1155/2004/219293

34. Cyll K, Ersvaer E, Vlatkovic L, et al. Tumour heterogeneity poses a significant challenge to cancer biomarker research. $\mathrm{Br} J$ Cancer. 2017;117(3):367-375. doi:10.1038/bjc.2017.171

\section{Publish your work in this journal}

Cancer Management and Research is an international, peer-reviewed open access journal focusing on cancer research and the optimal use of preventative and integrated treatment interventions to achieve improved outcomes, enhanced survival and quality of life for the cancer patient.
The manuscript management system is completely online and includes a very quick and fair peer-review system, which is all easy to use Visit http://www.dovepress.com/testimonials.php to read real quotes from published authors. 